\title{
レーダー雨量を用いた流出予測システムとパラメータの同定 一四十四田流域を例として一 Study on Rainfall Runoff Prediction System for Radar Raingauge
}

\author{
清水尚志* 澤田晃二** 笹本 誠*** 堺 茂樹**** 平山健一***** \\ by Takashi SHIMIZU, Kouji SAWADA, Makoto SASAMOTO, Shigeki SAKAI, Ken-ichi HIRAYAMA
}

\begin{abstract}
Radar rainfall gauge gives a better information of rainfall distribution than the conventional Thiesen method. In the present study, a system for the prediction of rainfall-runoff is constructed. This system includes packages to obtain a channel network from the digital map, to combine the radar rainfall information with the channel network, and to calculate the runoff using the kinematic wave model.

This paper described the each package of the system. And parameters of the kinematic wave model were obtained for 20 runoff events in 1990 and 91 . Application of this rainfall runoff prediction system to dam reservoiurs is possible with several minor improvements of the system.
\end{abstract}

keywords : radar raingauge, digital map, channel network,

rainfall runoff, kinematic wave model

1.はじめに

近年、建設省により日本各地にレーダー雨量計が設置され、日本全土がレーダー雨量計によって覆われ、 これによって今までの点的な雨量分布の観測であったものに対し面的な雨量分布を5分毎に観測することが 可能になった。これまでに様々な形で流出解析が行われてきているが、レーダー雨量計の整備に対応して、 分布型流出モデルがいくつか提案されている。この場合、解析を行おうとする流域を小流域に分割すること になるが、従来は地形図を元に手作業で行われてきており、作業が非常に煩雑であるなどの難点があった。 このため、国土数値情報など地形データが整備されてきていることを背景に、計算機を利用した水文地形の 表示の自動化が研究されている。

本研究では北上川水系四十四田ダム流域を対象として、国土数值情報の標高デー夕を用いた擬河道網を作 成し、レーダー雨量を与えてkinematic-wave法で流出解析を行い、流出予湘計算のためのシステムのパラメ 一タの検討を行った。

\begin{tabular}{|c|c|c|c|}
\hline * & 学生貝 & & 岩手大学大学院工学研究科修士課程土木工学専攻 \\
\hline$* *$ & 学生貝 & & 岩手大学大学院工学研究科修士課程土木工学専攻 \\
\hline *** & 正員 & & 岩手大学技官 工学部建設環境工学科 \\
\hline$* * * x$ & 正員 & 工博 & 岩手大学助教授 工学部建設環境工学科 \\
\hline$* * * *$ & 正員 & Ph. D & 岩手大学教授 工学部建設環境工学科 \\
\hline
\end{tabular}




\section{2. 対象流域の概要と解析手法}

本研究で流出解析の対象とした流域は図ー 1 に示す岩手 県北部に位置する北上川上流域の四十四田ダム流域で、流 域面積は $1196 \mathrm{~km}^{2}$ である。擬河道網の作成に使用した国土数 值情報の標高デー夕は、四十四田ダム流域が含まれる、東 経 140 度 51 分 0 秒、北緯 40 度 5 分 45 秒の地点から東へ $60 \mathrm{~km}$ 、南 へ43kmの部分を使用した。

雨量データは図ー 1 に示す、岩手県南部に位置する物見 山の建設省物見山レーダー雨量計で観測された、1990年4月 から1991年10月までのうち、台風、前線を含め比較的大き な流出量を記録した降雨のレーダーデータのうち20例を用 いた。

\section{3，国土数值情報を用いた擬河道網}

国土数值情報の標高データから、流出解析を行う対象流 域の標高データを作成し、その標高データから標高が与え られた各点で、最急勾配方向を求め、流域全体での落水線 を描くことができる。四十四田ダム流域について作成した 落水線図（しきい值 1 ）の一部を図一2に示す。完成した

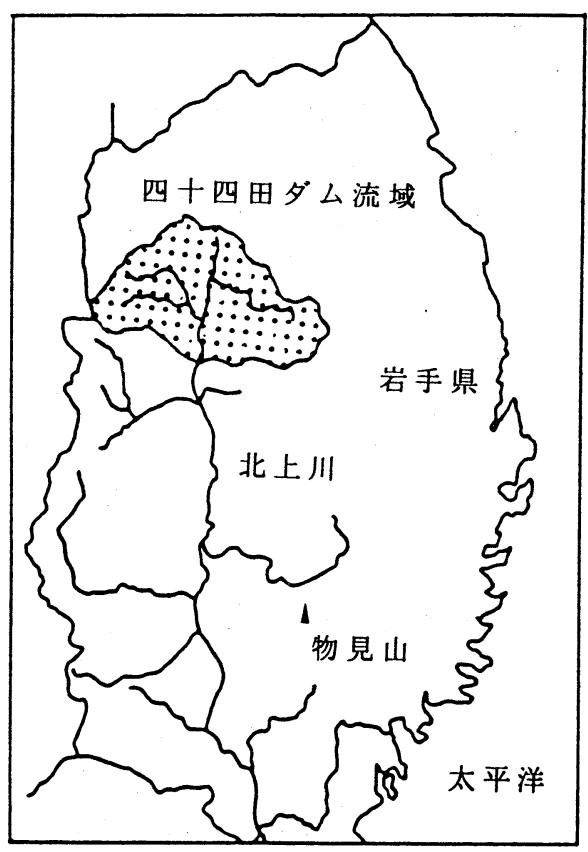

図一１四十四田夕ム位置図 落水線に、何地点からの水流を集めたかを示す番号

（集水地点数）をつける。最上流点は 1 となり、こ の番号は下流へ行くほど大きくなる。さらに主要河 道の決定、ダム位置の決定、しきい値による擬河道 網の最上流端の決定、合流先の判定などの過程を経 て、擬河道網の作成を行った。擬河道網は、落水線 図の中で適当なしきい値を決め、この値より小さな 番号の落水線を除いてつくられるものである。しき い值を大きくしていくと、細流は省かれていき、穾 際の河道に近いものが得られる。

5 万分の一地形図に基づく四十四田ダム流域にお けるHorton-Strahlear位数による河道の最大位数は 6 で、擬河道網では最大位数が6であるのはしきい 值 15 までである。分割された小流域の数がもっと も近かったのはしきい值 19 の場合であったが、河
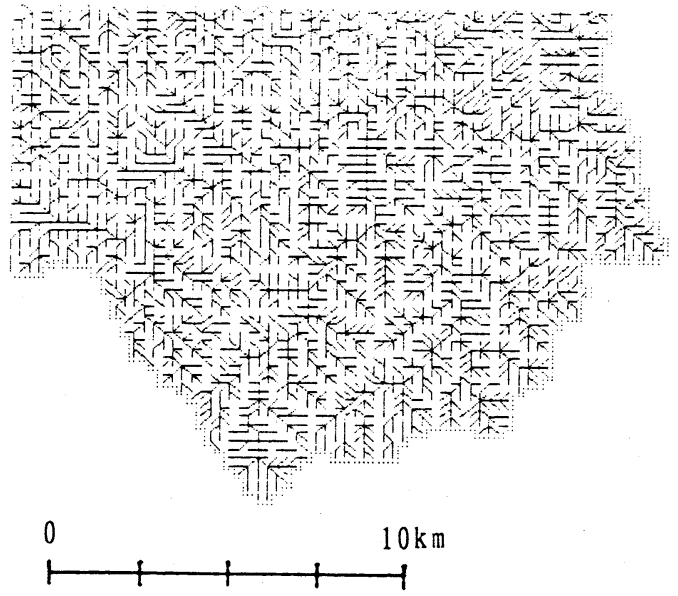

図 -2 落水線図 道形状、河道特性量が近かったのは、しきい值 15 の場合であった。しきい值 15 の擬河道網は図ー3のようになる。また、流域面積は地形図の1196km²対し、 擬河道網では $1175 \mathrm{~km}^{2}$ となり、2\%弱の差を持つ程度で害際の河道をよく再現している。

50 万分の 1 地形図に示された主要流路と、しきい值 2000 場合の擬河道網を比較したのが図ー4であ り、全体的配置がきわめてよく一致しているのが認められる。

上述のようにして求められた擬河道網では、分割した各小流域における流域面積、河道長、河道勾配、斜 面勾配などの諸特性量を算出している。このようにして求められた流域地形データに、レーダー降雨データ を与えkinematic-wave法で対象流域の流出量を算出する。計算に必要なパラメー夕は流出摔、河道粗度、斜 
面粗度、有効雨量に関する定 数の 4 個である。さらに、フ ィードバックの機構を組み込 むことによって流出量の予測 、及び流出量の予測精度の向 上が可能であるといえる。

以上の手順を図ー5のフロ 一チャートで示す。

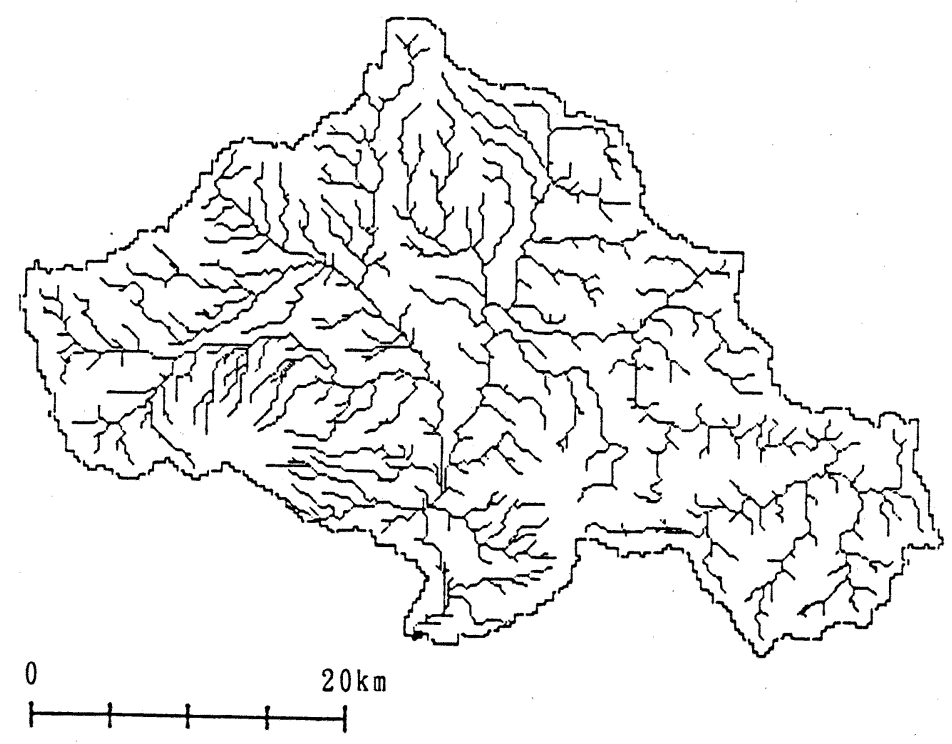

図一 3 擬河道網（しきい値 15 )

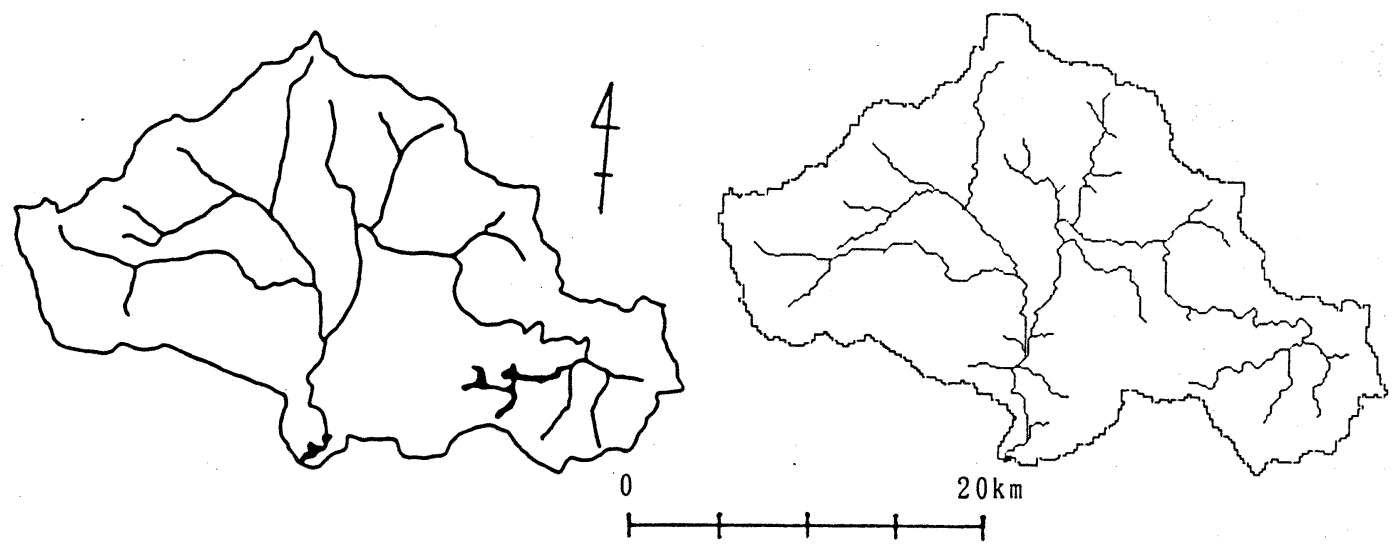

図-450万分の 1 の地形図による主要河道網としきい值 22000 の擬河道網

4. 小流域へのレーダーデータの対応

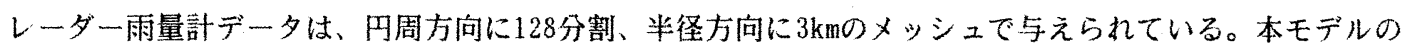
流出計算では、この極座標のメッシュを直交座標のメッシュに変換し、これを擬河道網に重ね合わせて計算 を行う。

小流域の平均面積は、擬河道網では1.7kmでありレーダーメッシュょり小さい。そこで、小流域での降雨 強度は小流域の重心が位置するレーダーメッシュでの降水値を用いるこレにする。

地形図に基づく方法では、地形図とレーダーメッシュマップを重极合わせ、小流域の中心位置のレーダー メッシュの番号を読みとるという煩雑な作業が必要があったが、国土数值情報を用いることによって、レー ダーサイトの経緯度を与えるだけで自動的に小流域での降雨強度が得られるようになっている。 
5. 铞討方法及び結果

以九の上うに決定された擬河道網 にレーダーデータを重极合わせkine matic-wave法を用いて流出解析を行 つた。計算に必要なパラメータは斜 面粗度、河道粗度と、次式で与えら れる流出率 $\mathrm{f}$ 、a定数の4つを用いた。

$$
r_{*}=r_{0}\left(1-\exp \left(a \sum r\right)\right)
$$

ここで $\mathrm{r}_{\mathrm{e}}$ は有効雨量、 $\mathrm{r}$ は実測降 雨を示す。また、実測降雨の累加範 囲は、降雨の降り始めからのものを 用いた。各パラメータの最適値はハ イドログラフの立ち上がり部分とピ 一ク流量に注目し、本モデルの計算 值の流量とダム位置での実測流量が 合致するときのものを試行錯誤によ って求めた。このようにして求めた パラメータを用いたときの観測流量 と計算流量を比較したものを図ー 6 に示す。しかし、これらのパラメー 夕は、実際に予測を行う場合には予 め与えておく必要がある。そこで各 パラメータをいくつかの水文量との 相関を調べた結果、比較的よい相関 が得られたのは、各出水毎の最適パ ラメー夕を流出の始まる以前の流量 (初期流量)と比較したものであっ た。これを図ー7に示す。図の直線 はプロットした点から最小 自乗法で引いたものである。 この直線の近似式を求め、 その式に初期流量を与え各 パラメータを算出する。図 ー7で求めた近似式を用い て算出したパラメータを用 い再度流出計算を行い、観 測流量と計算流量の比較を 行った結果が図ー8である。 この図から、計算値と実測 值ではピーク流量の発生す る時間はほほ合致している といえる。

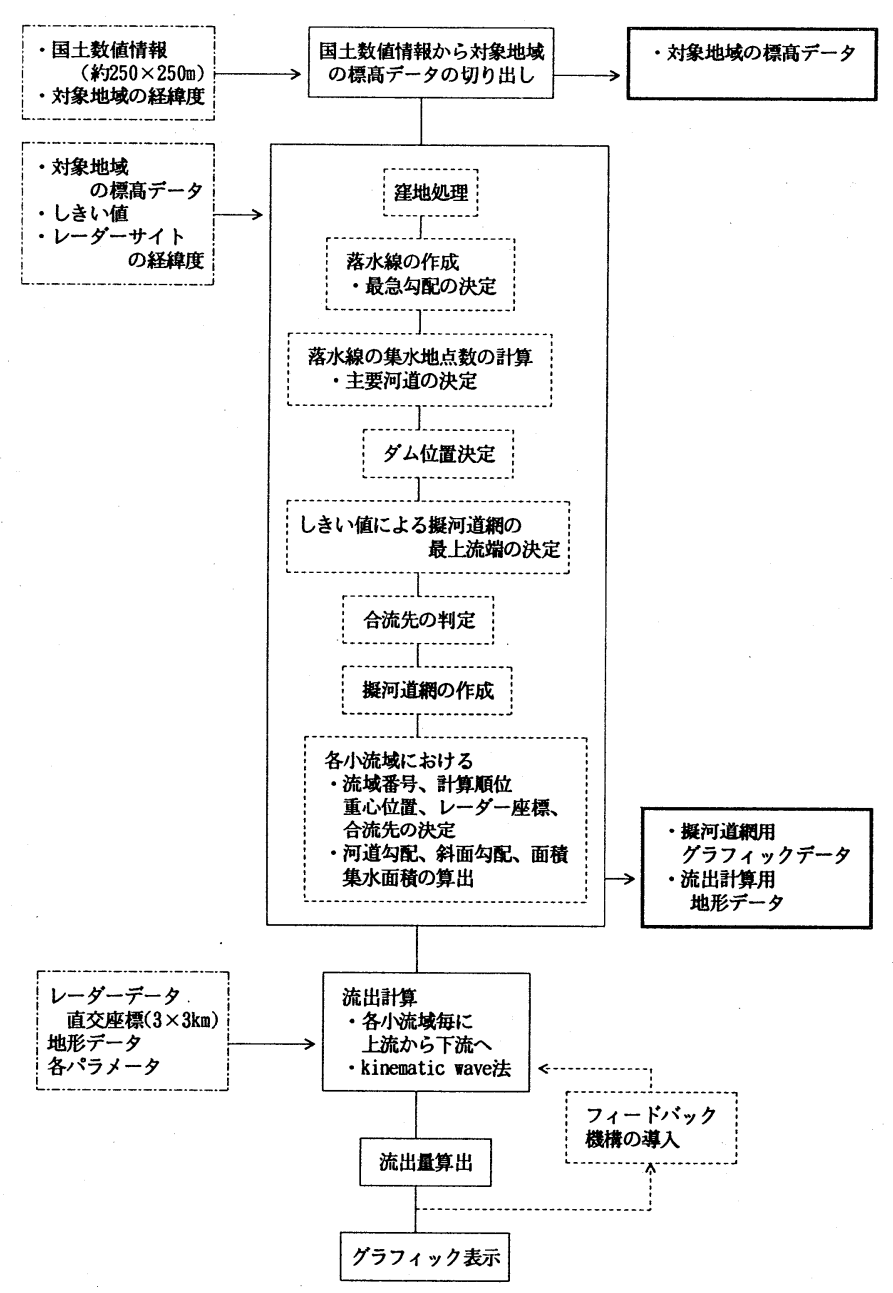

図一 5 フローチャート
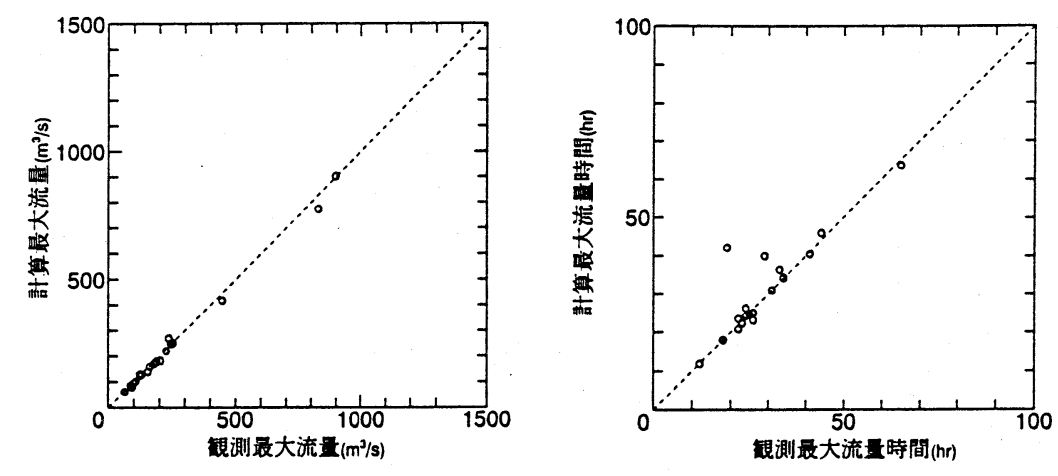

図 -6 計算值と実測值の比較（最適パラメータ） 
しかし、ピーク流量については計算値と実測值 の量的な過不足が大きく、洪水波形も寒測值と の適合はあまり良くない。

つぎに、計算結果にもっとも大きな影響を与 えると考えられる流出率乱には、最適パラメー 夕を用い、他のパラメー夕は上述の近似式で求 めたものを与えて再度計算を行った。この計算 結果を図一8と同様にプロットすると図ー9の ようになる。図一 8 と比較すると、計算値と実 測値のピーク時間の発生時刻はあまり变化がな く良い結果が得られた。ピーク流量はすべての パラメータを近似式で求めた場合と比較して、 かなり良い結果が得られている。この計算結果 より、流出率の算定が計算結果に与える重要性 は明らかであり、流出予測を行う場合、流出率 の決定が流出量予測には非常に重要であること がわかる。
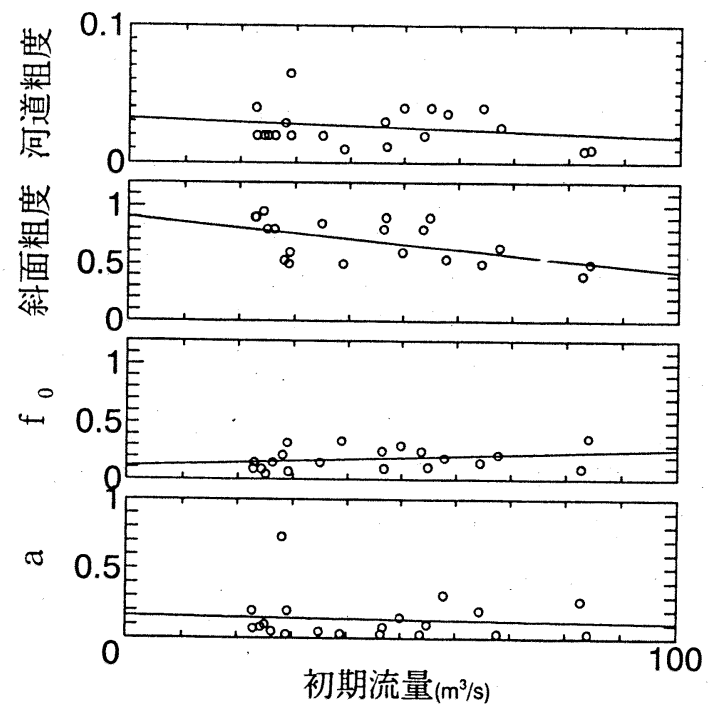

図一 7 各パラメー夕相関図
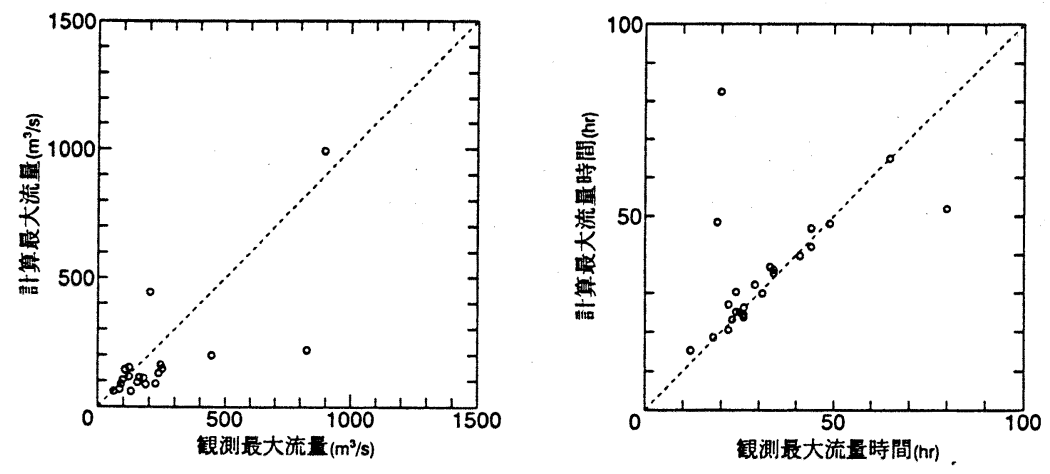

図-8 計算值と実測值の比較（相関式によるパラメータ）
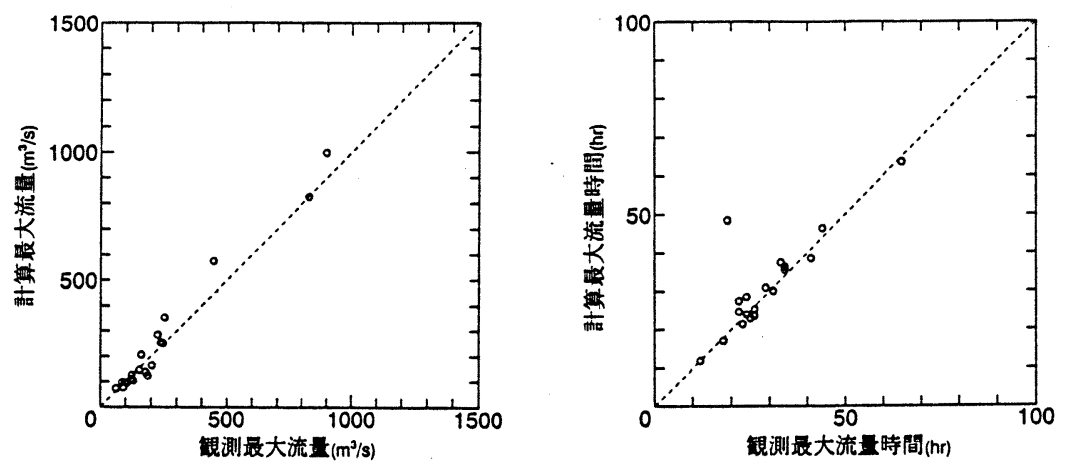

図 -9 計算值と実測值の比較

(相関式によるパラメータと最適パラメータ $\mathrm{f}_{0}$ ) 


\section{6. 今後の課題}

以上のように、国土数値情報の標高データのみを用いて、擬河道網を作成し、各小流域の計算順序の判定、 擬河道網とレーダーデータの対応の流出計算システムの作成などについて自動化を行った。また、各パラメ 一タを近似式で与えることで、流出量の予測がある程度可能であることが明らかとなった。 本モデルを用 いて流出量予測を行う場合、すべてのモデルのパラメータを既知の水文量から予め与える場合には誤差が大 きくなりすぎるという結果が得られたので、流出量の予測の精度を向上させるためには、フィードバックの 機構をモデルに取り込むことが必要と判断される。本モデルの流出計算におけるパラメータの中では流出率 に関わる係数が最も重要であり、䑙の值に着目したフィードバック機構の開発が必要であるといえる。

また、対象としている四十四田ダム流域の場合、東西の流域で流出特性の違いがあり、その原因として東 側流域はほとんどが樹林帯であるのに対し西側流域は東側流域に比べ水田が多い、などの土地の利用形態及 び植生、被覆、地質等に大きな違いがみられた。今後はこれらの情報を与えることによって予測精度が向上 すると考えられる。

\section{謝辞}

本研究を進めるにあたり、建設省東北地方建設局北上川ダム統合管理事務所、財団法人河川情報センター から貴重なデータを提供していたたいたことを記し、ここに感謝の意を表します。

\section{参考文献}

1) Divid G. Tarbonton: The analysis of river basins and channel networks using digital terrain data, Sc. D. Tesis, Dept. of Civil Eng, MIT, 1989

2)宝・高棹・淟㴊 : 水文地形解析の自動化の試み、第32回水理講演会論文集、1988

3) 伊藤・笹本・堺・平山: 国土数値情報とレーダ一雨量情報を用いた流出解析の自動化、水工学論文集第 36 巻、 1992 